\title{
From Traditional to Applied: A Case Study in Industrial Engineering Curriculum
}

\author{
Hani Shafeek ${ }^{1}$ Mohammed Aman*2 ${ }^{2}$ Muhammad Marsudi ${ }^{3}$ \\ ${ }^{1,2,3}$ Department of Industrial Engineering, Faculty of Engineering, \\ King Abdulaziz University, Rabigh, Saudi Arabia \\ ${ }^{1}$ Suez Canal University, Industrial College of Education, Egypt
}

\begin{abstract}
Applied Industrial Engineering is the application of management and technical skills for the design of new products, integration of production and/or information systems and the improvement of manufacturing processes. The purpose of this case study is to present the results of an initial research study conducted to identify the desired professional characteristics of an industrial engineer with an undergraduate degree and the emerging topic areas that should be incorporated into the curriculum to prepare industrial engineering (IE) graduates for the future workforce. Various principal findings and recommendations for applied industrial engineering coursework have been put together.
\end{abstract}

A two-pronged approach was taken which included a method of benchmarking by comparing the applied industrial engineering curricula of various universities and an industry survey to identify job market requirements. This methodology produced an analysis of the changing nature of industrial engineering from learning to practical education. Curriculum studies for engineering is a relatively unexplored area of research in the Middle East, much less for applied industrial engineering. This paper examines the key economic industrial sectors that are rapidly developing and their growing demands for qualified industrial engineers and how the design of an applied industrial program can help satisfy industry needs whilst reducing the gap between the classroom and the real world.

Keywords Universities, Curriculum, Traditional industrial engineering, Applied industrial engineering

\section{Introduction}

Applied engineering education has a larger scope of improvement compared to other fields of education such as law and medicine. The issue is resistance to change from the traditional IE curriculum to an applied IE curriculum - the resistance coming from both educators as well as students. The lecture and laboratory methods used in traditional IE education seem quite inadequate from the industry perspective in terms of sustainability. This paper is an attempt to initiate discussion to address the following questions: How can multi- and transdisciplinary teaching and research coexist in a meaningful way in today's university structures? Does education relevant to sustainable development require its own protected incubating environment to survive, or will it otherwise be gobbled up and marginalized by attempting to instill it throughout the traditional curriculum? What roles can governments have in accelerating the needed changes? How can it be made safe for courageous students to take educational paths different from traditional tracks, even if technical options do exist? What can one learn from comparative analysis of the curricula of universities in different nations and environments?

Based on the themes and questions mentioned above, this paper produces an analysis of the changing nature of engineering from learning to practical education; from Traditional Industrial Engineering to Applied Industrial Engineering. Engineering education should be focused on how to prepare engineers with strong applied sillks such as leadership, team work, analytical skills, creativity, communication skills and professionalism. The following is a brief discussion of the previous studies related to the critical factors needed for applied engineering education.

\subsection{Teaching Quality Monitioring}

Monitoring the quality of instruction was studied in an engineering perspective by Parashar, A. K. and et al [1] who reviewed aspects of curriculum process such as policy, analysis, objectives, content, evaluation methodology and implementation. Therefore, the need for transformation in curriculum for all the engineering educational and higher education levels becomes necessary. Burli, S. and et al [2] investigate the dimensions of TQM, analyze interrelationships and their combined influence on results achieved in ISO certified engineering institutes in India.

\subsection{Training Development}

Studying the importance of training of engineering graduates, Idris, A. and Rajuddin, M. [3] reported that the current trend in engineering education in Nigeria has created a disparity between the quality of training received by the graduates vis-à-vis the employers
*Corresponding Author

E-mail: maman1@kau.edu.sa; Phone: +966 590622710

(C) 2013. The authors - Published by Atlantis Press 
expectations in the business and industries in the country despite its enormous resources. In order to ensure the rapid reproduction of skills and functions of engineering activities by students, they are included in the "habitat" and they participate in the implementation of real projects.

\subsection{Technical Skills}

The critical nature of technical skills in appied engineering was discussed by Nurdin, M. [4] who report POLMAN Bandung as one of the applied higher education institutes having a unique approach in developing and implementing manufacturing technologies training through partnerships with industry for the purpose of increasing added value and benefits for both parties. Sansom, C. and Shore, P. [5] investigated the work aims to demonstrate how science and engineering graduates can be recruited and trained to Masters level in precision engineering as an aid to reducing the skills shortage of mechanical engineers in UK industry.

\subsection{Case Studies and Projects}

Researching the utility of having engineering students work on case studies and real life projects J. Goggins [6] investigated a number of initiatives in civil engineering undergraduate programmes at the National University of Ireland, Galway (NUIG) that allow students to complete engineering projects in the community, enabling them to learn by doing.

\subsection{Engineering Ethics}

Studying the issue of ethics in engineering, Byrne, E.P. [7] reports that the purpose of his work is to ascertain the engagement and response of students to the teaching of engineering ethics incorporating a macro ethical framework whereby sustainability is viewed as context to professional practice.

\subsection{Stake holders}

A comparative assessment between internal and external customers of the educational system, the internal customers being the faculty and the administrative staff, and the external customers being students and the industry was empirically tested and investigated by Sahney, S. [8]. Such an emphasis on customers of the educational system would assure a customer-centric design of the educational system. The work helped identify the quality components, which would help design quality for institutes of higher education.

\subsection{Sustainable Development}

An investigation and analysis of the process of changing engineering universities towards sustainable development (SD) was conducted by Mulder, K.F. et al [9]. It outlines the types of changes needed, both in respect of approaches, visions, philosophies and cultural change, which are crucial for engineering universities.

\subsection{Entrepreneurship Education}

Treanor, L. [10] investigated the policy background and extant literature pertaining to the contribution of entrepreneurship education for graduates and employers.

Clearly the industrial engineering curriculum needs a major overhaul. To some degree, this will require modernizing the approaches to science and mathematics instruction, paving the way to a new applied engineering curriculum. It is clear from the previous studies that there is a shortage in researches on continuous improvement of applied engineering. A survey of applied engineering based on critical factors in faculty of engineering is very important to be studied. The study investigates the effect of different parameters on applied engineering and its continuous improvement. In this paper, the critical factors of applied IE improvement initiatives are identified. An approach to applied IE ethics, which diverges applied IE from traditional IE, is proposed.

\section{Methodology}

The status of industrial engineering education in the concluded that the primary emphasis of IE program on scientific fundamentals has led to a weak link to engineering practice. Industrial engineering education must be transformed to embrace both fundamentals and practice - traditional procedural knowledge as well as problem solving skills of applied industrial engineering.

There are two methods used in this study:

1. Literature survey and comparison of the curriculum of applied industrial engineering curriculum at twelve universities - both local and global.

2. Analysis of market survey for applied industrial engineering curriculum.

\subsection{Literature Survey and Comparison of Applied Industrial Engineering Curriculum}

Comparison of curriculums was made among twelve (12) selected universities from the Kingdom of Saudi Arabia, U.S.A, Canada, South Africa, Oman and UAE as shown in Table 3.

The naming of the undergraduate program in Applied Industrial Engineering slightly varies among the universities. Specifically, the most popular name is "B.Sc. Applied Industrial Engineering" as used by University of Stellenbosch, Indiana State University and Stark State College. Other variations of program names include B.Sc. in Industrial Systems Technology (AB Tech) and Bachelor of Applied Science in Industrial Technology and Management (Macomb, FSU). Despite the slight differences, all of them fall within the same scope of applied industrial engineering.

\subsubsection{Discussion}

An analysis of the data in table 1 from the comparison of various universities as shown in figure 1 offering 
applied industrial engineering programs, it is observed that practical courses like Simulation, Quality, CAD/CAM as well as Summer Training and Industrial Internship are offered by most universities. At the other end of the spectrum, we notice Design of Industrial
Experiments, Strategic Management in Industry, DFMA, etc. fare poorly in the comparison despite being core IE subjects due to their theoretical approach as well as being courses preferred for grduate level programs.

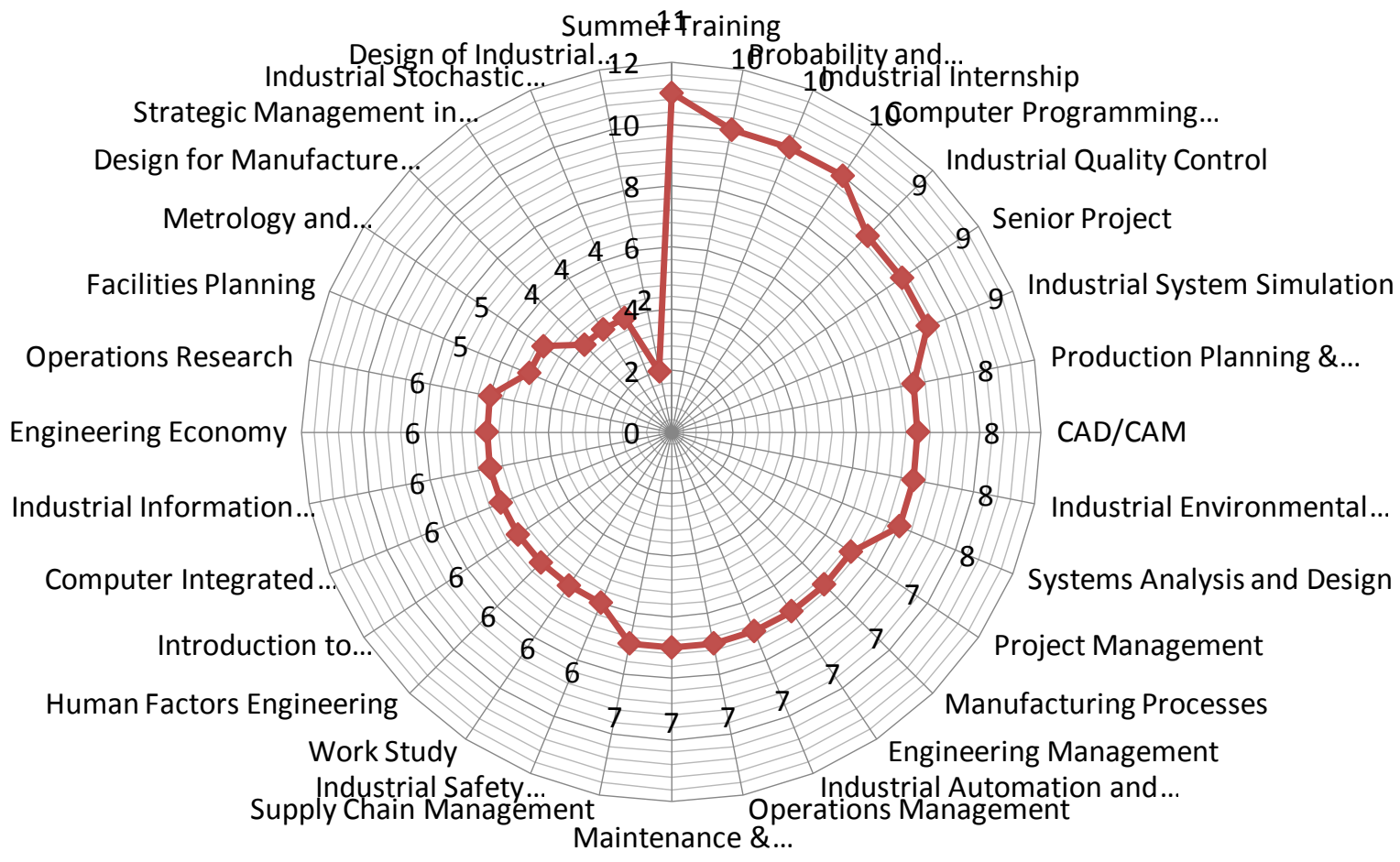

Fig.1. Results of University Comparison for Applied IE

\subsubsection{Specific Comparison of the IE Programs}

Applied Industrial Engineering is the application of industrial engineering in specific industries. In order to achieve this, industrial engineers apply their ability to specialize in specific industries like primary and secondary manufacturing, technology, finance and services.

The coursework of the twelve selected applied universities was compared and the following core IE courses were found to be critical in every applied curriculum:

(i) Computer Programming for Engineers: Computing skills and ability to use computers for problem solving are critical for practicing industrial engineers. All the Applied IE programs, excluding HCT Oman and UAE, include a computer programming course spanning from basic computer skills, structure computer programming, database systems (industrial information system). KAU program gave heavy emphasis on computer application in IE. (ii) Project Management: Most of the compared universities have a course in Project Management except for ISU, HCT, KFUPM and UT.

(iii) CAD/CAM: Computer Aided Design and Computer Aided Manufacturing is an important hands-on course for applied industrial engineering. All universities included CAD/CAM in their curriculum except FSU, HCT (UAE), KAU-Jeddah, KFUPM and UT.

(iv) Industrial Quality Control: Except for Cuyahoga, HCT (UAE) and AB Tech all other universities offer a Quality Control course in their curriculum albeit by slightly different names.

(v) Industrial Safety Engineering: Few universities have not included Safety Engineering in their required coursework making it an important course for applied industrial engineering.

(vi) Production Planning and Control: All the compared universities have a course in Production Planning and Control except Cuyahoga, AB Tech, Stark State and HCT (UAE). 
(vii)Senior Project: With the focus on practical application and case studies to transfer theoretical knowledge into practical skills, most applied programs require a Senior Project to be completed before graduation. This could be a single course or a two part project with a proposal and research phase followed by the implementation phase in concurrent semesters.

\subsection{Field Survey to identify job market requirements - Applied IE}

Discussion on field study is presented with respect to the survey methodology and the survey findings.

\subsubsection{Methodology of Survey}

An industry survey was conducted by IE staff members during the summer training program in 2012 and responses were received from ten companies from various industrial sectors in Saudi Arabia. The survey questionnaire receiving 176 responses from the 29 companies surveyed, the results have high value due to the fact that all of the respondents were managers, directors or supervisors of their respective companies.

2.2.2 Survey Findings

The data obtained was statistically analyzed using SPSS software and also using a two-tailed analysis and the results were corroborated to give us deep insight into the relative importance of various courses to be included in the applied industrial engineering curriculum. Both methods are described below followed by a conclusion of the results of the findings. The industry survey responses were statistically analyzed by giving weights to the responses as follows:

5 - Extremely Important

4 - Very Important

3 - Important

2 - Somewhat Important

1 - Not Important

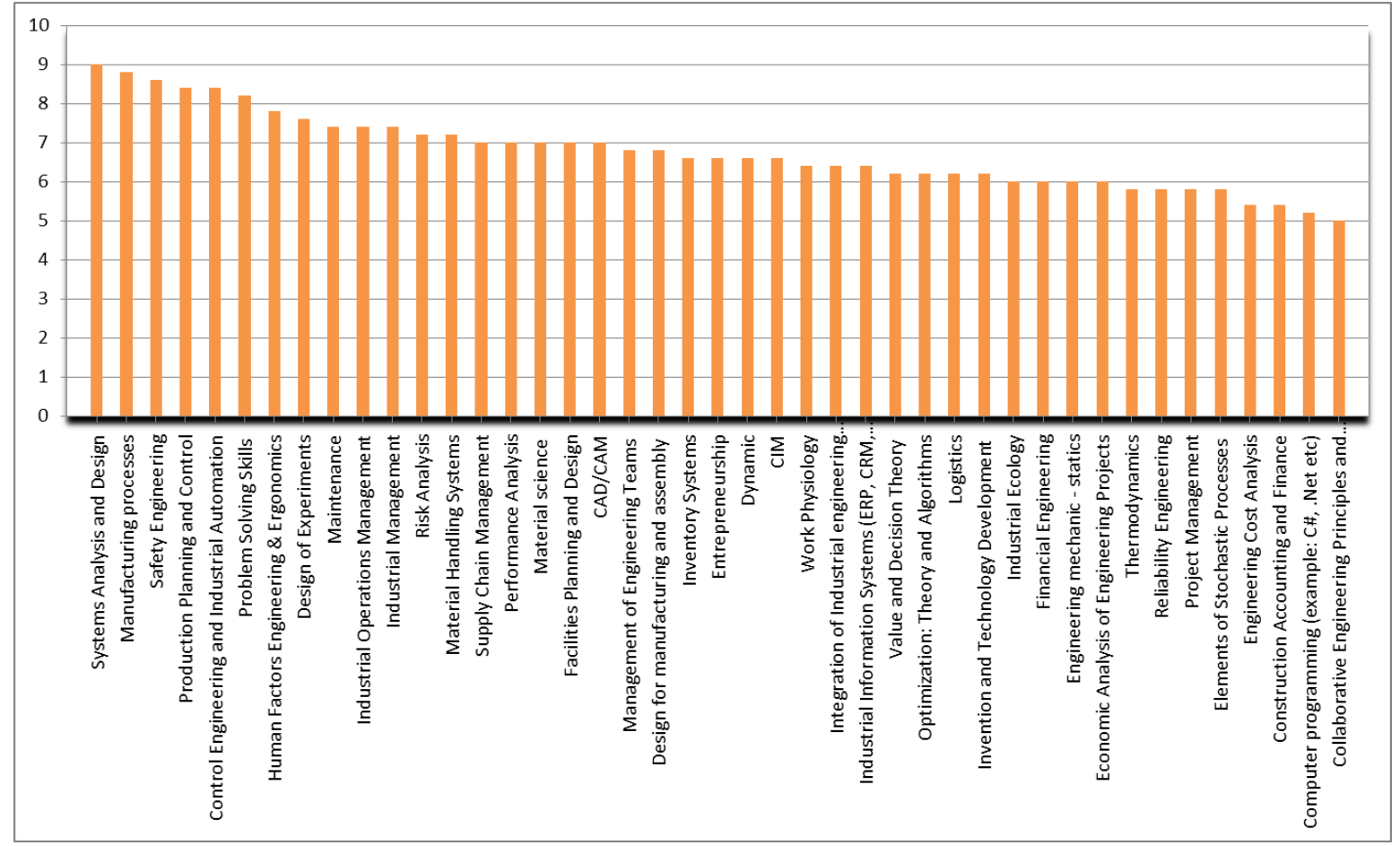

Fig. 2. Course Grading by Weighted Analysis of Survey Responses

From a statistical analysis of the survey responses as shown in figure 2 the following courses were found to have mean frequency of response below 6.4 (standard deviation 4.65) and hence fell to the lower end of the spectrum of decreasing importance.

- Work Physiology

- Integration of Industrial Engineering Techniques

- Optimization: Theory and Algorithms

- Industrial Ecology

- Collaborative Engineering Principles and Practice
- Industrial Information Systems

- Value and Decision Theory

- Invention and Technology Development

- Logistics

- Project Management

- Financial Engineering

- Economic Analysis of Engineering Projects

- Engineering Cost Analysis

- Construction Accounting \& Finance

- Engineering Cost Analysis 
Courses having a mean frequency of response above 7 were considered to be on the top end of the spectrum and highly preferred by prospective employers as skills that an applied industrial engineering graduate must acquire before joining the workforce. These are the core applied industrial engineering courses and even though some of them may still be inherently theory-heavy, their practical applications have high potential importance from the perspective of the workplace.

\section{Fig. 3. Systems Analysis and Design}

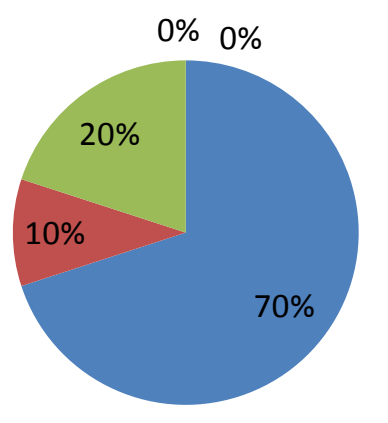

\author{
- Extremely \\ Important \\ - Very Important \\ Important \\ - Somewhat \\ Important \\ Not Important
}

- Systems Analysis and Design (Fig. 3)

- Manufacturing Processes

- Safety Engineering

- Production Planning and Control

- Control Engineering and Industrial Automation

- Problem Solving Skills

- Human Factors Engineering \& Ergonomics

- Design of Experiments

- Maintenance

- Industrial Operations Management

- Industrial Management

- Risk Analysis

- Material Handling Systems

The analysis left us with a middle group of "Important" courses that reinforced their notion as being typical IE courses like CAD/CAM, Supply Chain Management, Inventory Systems, etc.

\subsubsection{Two-Tailed Analysis}

Next, a tailed comparison was done to understand the survey responses at the extreme ends of the spectrum for the courses that were strongly recommended and those that were not considered important for applied industrial engineering curriculum.

From an analysis of the courses that received the highest votes for Extremely Important, we find that Systems Analysis \& Design tops the list. $70 \%$ of respondents gave it the highest ranking in terms of importance for applied industrial engineering.

Hence we see that the industry considers practical courses like Problem Solving Skills, Safety and Maintenance as critical for inclusion in the applied industrial engineering curriculum.

Alternately, on the opposite end of the spectrum, we have courses that received "Not Important" tags. Construction Accounting \& Finance and Financial Engineering courses were not considered important by many respondents due to the fact that Engineering Cost Analysis and Engineering Economy were more suited from an applied engineering standpoint. Courses like Thermodynamics which $30 \%$ of respondents marked as Not Important are academically important to maintain compatibility with the FE exam requirements. Computer Programming also made it to the list with $30 \%$ Not Important votes but what the survey respondents failed to realize was that the Computer Programming syllabus for applied industrial engineering would not just include pure programming languages and coding but would focus on computer applications for the industry.

To conclude, the market survey of various industries both using statistical software as well as two-tailed analysis gives us a good understanding of the requirements of the industry for their engineer workforce.

\subsection{Correlation between University Comparison and Market Survey}

The results of university comparison and the market survey for applied engineering curriculum were correlated as shown figure 4. From the correlation diagram it is observed that there is positive correlation between the results of the university comparison and the industry survey. The course ranking decreases from right to left and from top to bottom .Most of the course fall in Quadrant I confirming their importance using both methodologies. Courses in Quadrant IV - namely Design of Industrial Experiments, Industrial Stochastic Systems, Design for Manufacture \& Assembly, Facilities Planning and Metrology \& Engineering Measurements - indicate their relatively high ranking on the survey but not many universities offered them as part of their applied industrial engineering programs. These courses are mostly offered by graduate programs in industrial engineering.

Summer training has the highest ranking both in terms of university comparision as well as industry survey. This indicates the importance of training - in various forms - in an applied engineering curriculum. Cooperative education is a system which integrates classroom study with paid on-the-job work experience. 


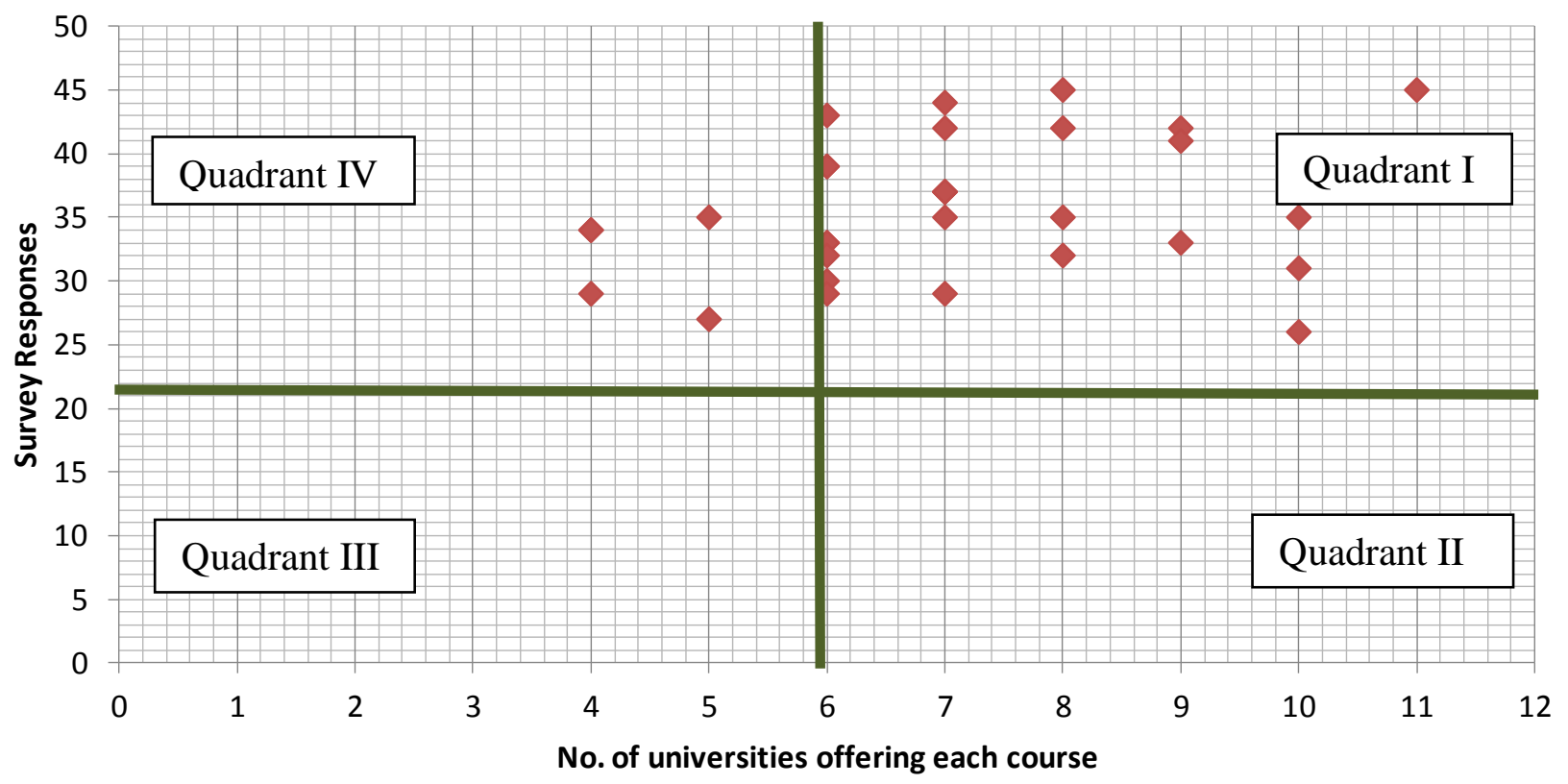

Fig. 4. Correlation between University Comparison and Market Survey

Entry into the co-operative education mode is the student's choice and is subject to an academic requirement. Students enrolled in the co-operative education option alternate periods of paid employment with college study. These periods are four months (one work term).

Cooperative education system include Summer training,training during the study, training leads to appointment, field visit and training paid salary. Co-op programs are offered in accordance with the following criteria:

- Each work situation is developed and/or approved by the College as a suitable learning experience;

- The student is engaged in productive work rather than merely observing;

- The student receives remuneration for work performed;

- The student's progress on the job is monitored by the college of Engineering

- The student's performance on the job is monitored and evaluated by both the employer and the college of Engineering.

- The total co-operative work experience is normally 30 to $50 \%$ of the time spent in academic study.

The summer training program is similar to the cooperative program in its objectives except that it lasts weeks. The student is required to follow the work rules and guidelines as any regular employee, and submit to the academic department a final report. The employer should assign a supervisor to the student to guide and help him achieve the training objectives, and submit one evaluation report about the student's performance.
From the comparison of universities, almost all universities include some form of training in their applied curriculum. A listing of the training types are listed below.

\section{The proposed Applied Industrial Engineering curriculum}

Introducing Applied Industrial Engineering as an elective specialization in conjunction with the traditional curriculum already in place led to the following modifications in the department curriculum.

General Education (Language, Social Science): No change in offering English Language and Technical Writing courses as part of the applied curriculum as language is one of the foundations of technical education.

Mathematics and Basic Sciences: One Mathematics course, Ordinary Differential Equations, was replaced by a course in Numerical Methods in Engineering to be offered by the Department of Electrical Engineering.

Computer Science: With the increased familiarity of students with computers and their exposure to latest technologies, the Fundamentals of Computers course was removed and replaced with a comprehensive course Computer Programming for Engineers that combines the previous Computer Applications for IE I \& II. More focus is on applying computer tools and software for design and manufacturing with the general Computer Aided Manufacturing Systems course being replaced by multiple specialized courses like CAD/CAM and CIM. 
Engineering Sciences: New courses were added to the curriculum with focus on application of concepts such as Basic Electrical Engineering (Electrical Circuits), Materials Science\& Engineering, Manufacturing Processes I \& II, Thermo-Fluids, and Metrology \& Engineering Measurements. Statistics I \& II were combined into a single course Probability \& Engineering Statistics.

Engineering Design: New courses for application in manufacturing include Manufacturing Systems Design and Design for Manufacturing and Assembly.

Management: The standard Engineering Management course offered by the IE curriculum was increased from 2 to 3 credits while the Industrial Management course was deleted.

Specialized IE courses: Besides the core IE courses like Production Planning and Control, Work Study / Ergonomic, Engineering Economy, Operations Research, Quality Control, more focus was given to application and practice by introducing a new Industrial
Internship course requiring students to intern full-time for a semester. The regular Summer Training had its credits increased from 0 to 2 hence having the grade now count towards the GPA. With the emphasis on inculcating entrepreneurial sills into students, the Introduction to Entrepreneurship course was increased from 1 to 2 credit hours. A new course in Global Logistics Management was also added to the Industrial Operations Management elective group.

For the applied engineering group as well as the other groups a comprehensive laboratory list was prepared including lab layouts, equipment, furniture and connections along with the list of experiments, etc.

The industrial engineering labs include Industrial System Analysis \& Simulation, Quality Engineering, Human Factors, Work Study \& Ergonomics, CAD/CAM, Information Systems \& OR, Active Learning Lab, Research Lab, Computer Lab for Students.

Based on the above analysis The following IE Course Modifications as shown in Table 1 have been made.

Table 1: IE Course Modifications

\begin{tabular}{|l|}
\hline \multicolumn{1}{|c|}{ NEW COURSES ADDED } \\
1. CHEN 210 - Materials Science \& \\
Engineering \\
2. EEN 100 - Electrical Circuits I \\
3. EEN 332 - Numerical Methods in \\
Engineering \\
4. IEN 361 - Manufacturing Processes I \\
5. IEN 362 - Manufacturing Processes II \\
6. IEN 363 - Manufacturing Systems \\
Design \\
7. MEN 367 - Thermo-Fluids \\
8. IEN 393 - Industrial Internship \\
9. IEN 455 - Global Logistics Management \\
10. IEN 461 - CAD/CAM \\
11. IEN 462 - CIM \\
12. IEN 463 - Design for Manufacturing and \\
Assembly \\
13. IEN 464 - Metrology and Engineering \\
Measurements \\
14. XXX xxx [2 free courses from outside \\
the faculty]
\end{tabular}

\section{OLD COURSES REMOVED}

1. MATH 205 - Ordinary Differential Equations

2. MATH 241 - Linear Algebra

3. IEN 321 - Fundamentals of Computers

4. IEN 351 - Industrial Management

5. IEN 395 - IE Seminar

6. IEN 423 - Computer Aided Manufacturing Systems

7. IEN 443 - Industrial Environmental Engineering

8. IEN 455 - Material Handling \& Packaging

9. IEN 491 - Industrial Engineering Practice

\section{COURSES COMBINED, REPLACED OR CHANGED}

1. EEN 201 - Comp Programming MATLAB is replaced by EEN 170 - Computer Programming

2. IEN 256 - Engineering Management ( 2 to 3 credits)

3. IEN 322 - Computer Programming for Industrial Engineers (name change)

4. IEN 323 - Systems Analysis \& Design (code change)

5. IEN 331 - Probability \& Engineering Statistics (combined $331+332$ )

6. IEN 390 - Summer Training (2 credits counted towards GPA)

7. IEN 481 - Intro to Entrepreneurship (2 credits). Pre-req IER 256 


\section{Elective Flowchart}

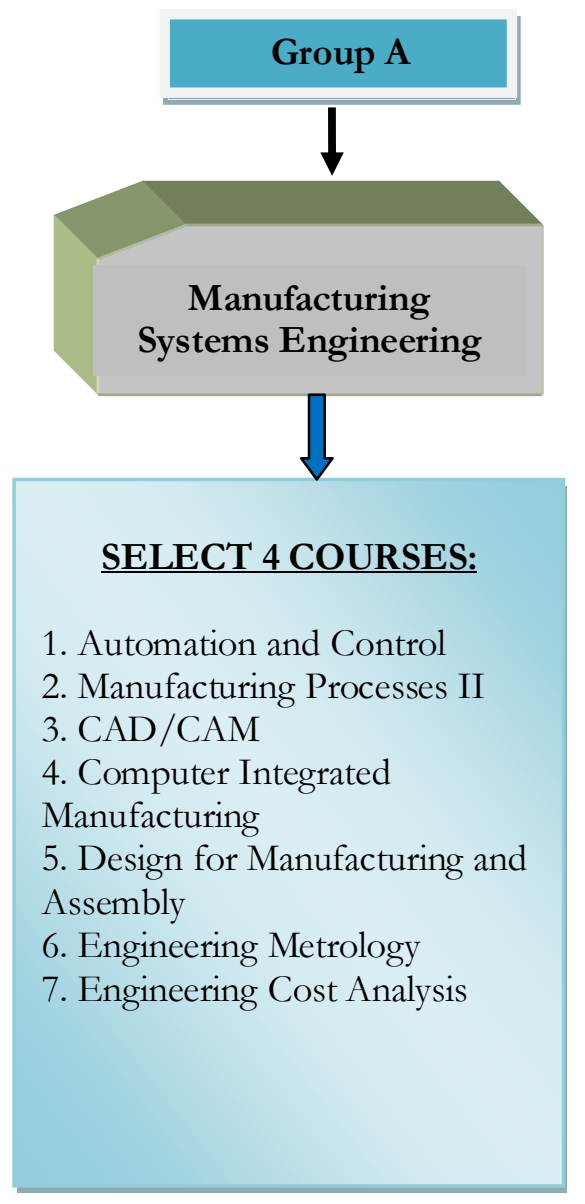

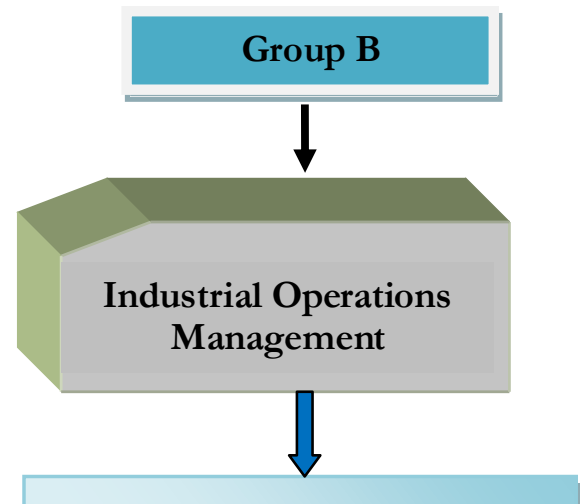

SELECT 4 COURSES:

1. Operations Research II

2. Industrial Stochastic Systems

3. Project Management

4. Strategic Management

5. Operations Management

6. Global Logistics Management

7. Supply Chain Management

8. Marketing Management and

Research

9. Feasibility Studies

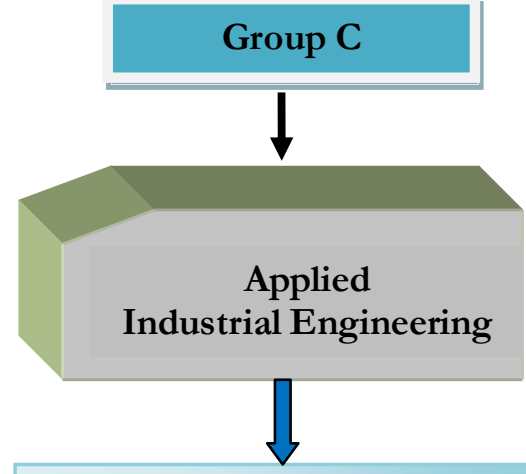

SELECT 4 COURSES:

1. Reliability Engineering

2. Maintenance Engineering

3. Industrial Safety Engineering

4. Industrial Data Systems

5. Engineering Cost Analysis

6. Engineering Metrology

7. Manufacturing Processes II

9. Industrial Internship

10. Special Topics in IE

Fig. 5. Proposed curriculum for Industrial Engineering Department

\section{Conclusion}

Applied engineering education still needs improvements compared to other fields of education such as law and medicine. It requires increased attention by universities and industry to support longterm applied engineering programs necessary to build the knowledge-base key to addressing industries needs. To conduct this study, we have chosen a strategy of roadmapping, beginning with traditional industrial engineering education and have identified why industrial engineering education should move away from the current dominance of classroom-based education to more active learning approaches that engage problem-solving skills and teamwork building. The industrial engineering curriculum at most universities was quite different in design and practical skills. As a result, most undergraduate industrial engineering programs today are, in reality, programs in applied science, although they pay sufficient lip service to design, technical writing, active learning and professional ethics.

The study concluded that there is positive correlation between the results of the university comparison and the industry survey for the courses that must offered by undergraduate programs in applied industrial engineering. Proposed curriculum for the Department of Industrial Engineering at KAU, Rabigh, consists of three tracks, manufacturing systems engineering, industrial operation management and applied industrial engineering as shown in figure 7. Course modifications consists of 13 courses added, 8 courses removed and 6 courses combined or changed. New 4 laboratories added as shown in table 3 . 
Table 3: Comparison of Applied Industrial Engineering Curriculums (selected courses)

\begin{tabular}{|c|c|c|c|c|c|c|c|c|c|c|c|c|}
\hline $\begin{array}{l}\text { University/ } \\
\text { Institute }\end{array}$ & $\begin{array}{l}\text { Indiana } \\
\text { State } \\
\text { University }\end{array}$ & $\begin{array}{c}\text { Macomb } \\
\text { Community } \\
\text { College, Ferris } \\
\text { State Univ }\end{array}$ & $\begin{array}{l}\text { Cuyahoga } \\
\text { Community } \\
\text { College }\end{array}$ & $\begin{array}{c}\text { Higher } \\
\text { College of } \\
\text { Technology }\end{array}$ & $\begin{array}{c}\text { Higher } \\
\text { College of } \\
\text { Technology }\end{array}$ & $\begin{array}{l}\text { Stark State } \\
\text { College }\end{array}$ & $\begin{array}{c}\text { AB Tech } \\
\text { Community } \\
\text { College }\end{array}$ & $\begin{array}{c}\text { Eastern } \\
\text { Illinois } \\
\text { University }\end{array}$ & $\begin{array}{c}\text { King } \\
\text { Abdulaziz } \\
\text { University }\end{array}$ & KFUPM & $\begin{array}{l}\text { University of } \\
\text { Toronto }\end{array}$ & $\begin{array}{l}\text { University of } \\
\text { Stellenbosch }\end{array}$ \\
\hline Location & $\begin{array}{l}\text { Indiana, } \\
\text { USA }\end{array}$ & $\begin{array}{l}\text { Michigan, } \\
\text { USA }\end{array}$ & Ohio, USA & $\begin{array}{l}\text { Muscat, } \\
\text { Oman }\end{array}$ & $\begin{array}{l}\text { Abu Dhabi, } \\
\text { UAE }\end{array}$ & Ohio, USA & $\begin{array}{c}\text { North } \\
\text { Carolina, USA }\end{array}$ & $\begin{array}{l}\text { Illinois, } \\
\text { USA }\end{array}$ & $\begin{array}{l}\text { Jeddah, } \\
\text { KSA }\end{array}$ & $\begin{array}{c}\text { Dhahran, } \\
\text { KSA }\end{array}$ & $\begin{array}{l}\text { Toronto, } \\
\text { Canada }\end{array}$ & $\begin{array}{c}\text { Stellenbosc, } \\
\text { South Africa }\end{array}$ \\
\hline $\begin{array}{l}\text { Faculty/ } \\
\text { Department }\end{array}$ & $\begin{array}{l}\text { Applied Eng } \\
\text { \& Tech } \\
\text { Mgmt }\end{array}$ & $\begin{array}{c}\text { Industrial Tech } \\
\text { \& Mgmt }\end{array}$ & $\begin{array}{l}\text { Applied } \\
\text { Industrial } \\
\text { Tech (Mfg } \\
\text { Tech) }\end{array}$ & $\begin{array}{l}\text { Engineering } \\
\text { Department }\end{array}$ & $\begin{array}{l}\text { Mechanical } \\
\text { Engineering }\end{array}$ & $\begin{array}{c}\text { Engineering, } \\
\text { Industrial } \\
\text { and } \\
\text { Emerging } \\
\text { Technologies }\end{array}$ & $\begin{array}{l}\text { Engineering } \\
\text { and Applied } \\
\text { Technology }\end{array}$ & $\begin{array}{l}\text { School of } \\
\text { Technology }\end{array}$ & $\begin{array}{l}\text { Industrial } \\
\text { Engineering }\end{array}$ & $\begin{array}{l}\text { College of } \\
\text { Eng } \\
\text { Sciences \& } \\
\text { Applied Eng }\end{array}$ & $\begin{array}{c}\text { Dept. of } \\
\text { Industrial } \\
\text { (System) Eng }\end{array}$ & $\begin{array}{l}\text { Applied } \\
\text { Industrial } \\
\text { Engineering }\end{array}$ \\
\hline Program & $\begin{array}{l}\text { Bachelors in } \\
\text { Industrial } \\
\text { Eng Tech }\end{array}$ & $\begin{array}{c}\text { Bachelor of } \\
\text { Applied } \\
\text { Science in Ind } \\
\text { Tech and Mgmt }\end{array}$ & $\begin{array}{c}\text { Applied } \\
\text { Science } \\
\text { Degree in } \\
\text { Applied Ind } \\
\text { Tech }\end{array}$ & $\begin{array}{l}\text { Bachelors in } \\
\text { Mechanical } \\
\text { Engineering }\end{array}$ & $\begin{array}{l}\text { Bachelor of } \\
\text { Applied } \\
\text { Science in } \\
\text { Mech Eng } \\
\text { Tech }\end{array}$ & $\begin{array}{l}\text { Bachelors in } \\
\text { Applied } \\
\text { Industrial } \\
\text { Technology }\end{array}$ & $\begin{array}{l}\text { Bachelors in } \\
\text { Industrial } \\
\text { Systems } \\
\text { Technology }\end{array}$ & $\begin{array}{c}\text { Bachelors } \\
\text { in Applied } \\
\text { Eng \& } \\
\text { Tech }\end{array}$ & $\begin{array}{c}\text { BSc. } \\
\text { Industrial } \\
\text { Engineering }\end{array}$ & $\begin{array}{c}\text { BSc. } \\
\text { Industrial \& } \\
\text { Systems } \\
\text { Engineering }\end{array}$ & $\begin{array}{c}\text { BSc. } \\
\text { Industrial } \\
\text { (System) Eng }\end{array}$ & $\begin{array}{l}\text { Bachelors in } \\
\text { Applied } \\
\text { Industrial } \\
\text { Engineering }\end{array}$ \\
\hline $\begin{array}{l}\text { Computer } \\
\text { Programming for } \\
\text { Engineers }\end{array}$ & $\checkmark$ & $\checkmark$ & $\checkmark$ & & & $\checkmark$ & $\checkmark$ & $\checkmark$ & $\checkmark$ & $\checkmark$ & $\checkmark$ & $\checkmark$ \\
\hline $\begin{array}{l}\text { Work Study \& } \\
\text { Ergonomics }\end{array}$ & $\checkmark$ & & & & & & & $\checkmark$ & $\checkmark$ & $\checkmark$ & $\checkmark$ & $\checkmark$ \\
\hline $\begin{array}{c}\text { Human Factors } \\
\text { Engineering }\end{array}$ & $\checkmark$ & & & & & & & $\checkmark$ & $\checkmark$ & $\checkmark$ & $\checkmark$ & $\checkmark$ \\
\hline $\begin{array}{l}\text { Industrial System } \\
\text { Simulation }\end{array}$ & $\checkmark$ & $\checkmark$ & & $\checkmark$ & $\checkmark$ & & & $\checkmark$ & $\checkmark$ & $\checkmark$ & $\checkmark$ & $\checkmark$ \\
\hline $\begin{array}{c}\begin{array}{c}\text { Manufacturing } \\
\text { Processes }\end{array} \\
\end{array}$ & $\checkmark$ & & & $\checkmark$ & $\checkmark$ & $\checkmark$ & $\checkmark$ & $\checkmark$ & & & & $\checkmark$ \\
\hline CAD/CAM & $\checkmark$ & $\checkmark$ & $\checkmark$ & $\checkmark$ & & $\checkmark$ & $\checkmark$ & $\checkmark$ & & & & $\checkmark$ \\
\hline $\begin{array}{c}\text { Industrial Quality } \\
\text { Control }\end{array}$ & $\checkmark$ & $\checkmark$ & & $\checkmark$ & & $\checkmark$ & & $\checkmark$ & $\checkmark$ & $\checkmark$ & $\checkmark$ & $\checkmark$ \\
\hline $\begin{array}{c}\text { Industrial Safety } \\
\text { Engineering }\end{array}$ & $\checkmark$ & $\checkmark$ & & & & $\checkmark$ & $\checkmark$ & $\checkmark$ & $\checkmark$ & & & \\
\hline $\begin{array}{c}\text { Production } \\
\text { Planning \& } \\
\text { Control } \\
\end{array}$ & $\checkmark$ & $\checkmark$ & & $\checkmark$ & & & & $\checkmark$ & $\checkmark$ & $\checkmark$ & $\checkmark$ & $\checkmark$ \\
\hline Summer Training & $\checkmark$ & $\checkmark$ & & $\checkmark$ & $\checkmark$ & $\sqrt{ }$ & $\checkmark$ & $\checkmark$ & $\checkmark$ & $\sqrt{ }$ & $\sqrt{ }$ & $\sqrt{ }$ \\
\hline $\begin{array}{l}\text { Industrial } \\
\text { Internship }\end{array}$ & $\checkmark$ & $\checkmark$ & $\checkmark$ & $\checkmark$ & $\checkmark$ & $\checkmark$ & $\checkmark$ & $\checkmark$ & & & $\checkmark$ & $\checkmark$ \\
\hline $\begin{array}{c}\text { Senior Project I \& } \\
\text { II }\end{array}$ & $\checkmark$ & $\checkmark$ & & $\checkmark$ & & $\checkmark$ & & $\checkmark$ & $\checkmark$ & $\checkmark$ & $\checkmark$ & $\checkmark$ \\
\hline $\begin{array}{c}\text { Systems Analysis } \\
\text { and Design }\end{array}$ & $\checkmark$ & $\checkmark$ & & & & & $\checkmark$ & $\checkmark$ & $\checkmark$ & $\checkmark$ & $\checkmark$ & $\checkmark$ \\
\hline $\begin{array}{l}\text { Introduction to } \\
\text { Entrepreneurship }\end{array}$ & & $\checkmark$ & $\checkmark$ & & & $\checkmark$ & & & $\checkmark$ & & $\checkmark$ & $\checkmark$ \\
\hline $\begin{array}{c}\text { Operations } \\
\text { Management }\end{array}$ & $\checkmark$ & $\checkmark$ & $\checkmark$ & & & & & $\checkmark$ & & $\checkmark$ & $\checkmark$ & $\checkmark$ \\
\hline $\begin{array}{l}\text { Supply Chain } \\
\text { Manage ment }\end{array}$ & $\checkmark$ & & $\checkmark$ & & & & $\checkmark$ & $\checkmark$ & & $\checkmark$ & $\checkmark$ & $\checkmark$ \\
\hline
\end{tabular}


The paper reflects experiences in case study form of one department and only local companies, drawing on established applied engineering principles. Based on the findings it is suggested that industrial engineering departments of other universities should enhance and expand industrial engineering education by focussing on applied engineering concepts, thus developing the potency of graduates to meet market requirements in developing economies.

\section{Suggestions}

The following are a list of suggestions to the Department of Industrial Engineering, Faculty of Engineering, King Abdulaziz University, Rabigh:

i. IE department must take advantage of the flexibility in the current accreditation criteria - in theory, at least, if not always in practice - in developing an innovative curriculum.

ii. IE Students should be introduced to the essence of engineering early in their undergraduate careers.

iii. IE departments must teach students how to be lifelong learners. After four-year study, students should accept the responsibility of working with local community, should be considered as a preengineer or engineer in training.

iv. IE students must depend on summer employment, cooperative education, and early employment to provide their first exposure to engineering practice and training.

\section{Future work}

To improve applied industrial engineering education, the following proposals have been put forward:

i. Collaboration between industry and universities to establish graduate professional industrial engineering departments that would offer practice-based degrees

ii. All stakeholders should commit the resources and leadership necessary to enable participation in restructuring of industrial engineering curriculum to achieve the benefits of applied engineering.

More efforts must taken to improve IE engineering education by moving in the right direction with stress on learning outcomes rather than simply on resource input.

\section{References}

1. Parashara, A.K. and Parasharb, R., "Innovations and Curriculum Development for Engineering Education and Research in India," Procedia Social and Behavioral Sciences, 56: 685 - 690, 2012.

2. Burli, S., Bagodi, V. and Kotturshettar, B. "TQM dimensions and their interrelationships in ISO certified engineering institutes of India International," Benchmarking: An International Journal Vol. 19 No. 2, 177:192, 2012.

3. Idris,A.and Rajuddin.M., "The Trend of Engineering Education in Nigerian Tertiary Institutions of Learning towards Achieving Technological Development," Procedia - Social and Behavioral Sciences 56, 730:736, 2012.

4. Nurdin, M., "Center of Technology (COT) for Industrial Product Development through Collaboration and Partnership in Polytechnic Education," Procedia - Social and Behavioral Sciences 52, 207:216, 2012.

5. Sansom, C. and Shore, P. "Case study: meeting the demand for skilled precision engineers," Education + Training Vol. 50 No. 6. 516:529, 2008.

6. J. Goggins "Engineering in communities: learning by doing," Campus-Wide Information Systems Vol. 29 No. 4, 238:250, 2012.

7. Byrne, E.P. "Teaching engineering ethics with sustainability as context," International Journal of Sustainability in Higher Education Vol. 13 No. 3, 232:248, 2012.

8. Sahney, S. "Designing quality for the higher educational system A case study of select engineering and management institutions in India," Asian Journal on Quality Vol. 13 No. 2. 116:137, 2012.

9. Mulder, K.F., Segala`s, J. and Balas, D.F. "How to educate engineers for/in sustainable development Ten years of discussion, remaining challenges," International Journal of Sustainability in Higher Education Vol. 13 No. 3, 211:218, 2012.

10. Treanor, L. "Entrepreneurship education: exploring the gender dimension," International Journal of Gender and Entrepreneurship Vol. 4 No. 2, 206:210, 2012. 